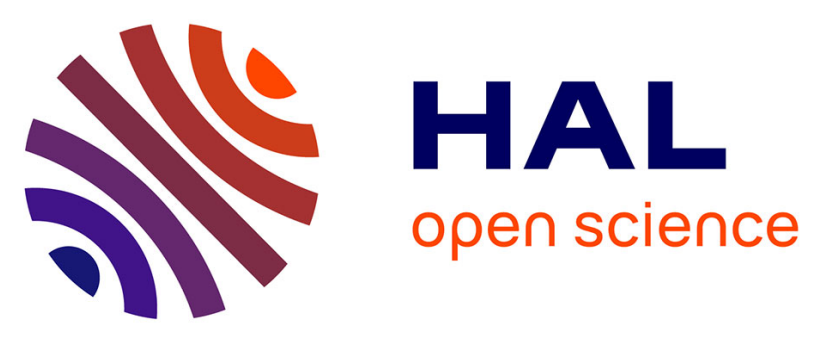

\title{
4-Aminoindoles as 1,4-bisnucleophiles for diversity-oriented synthesis of tricyclic indoles bearing 3,4-fused seven-membered rings
}

Shaomin Chen, Palanisamy Ravichandiran, Ahmed El-Harairy, Yves Queneau, Minghao Li, Yanlong Gu

\section{To cite this version:}

Shaomin Chen, Palanisamy Ravichandiran, Ahmed El-Harairy, Yves Queneau, Minghao Li, et al.. 4-Aminoindoles as 1,4-bisnucleophiles for diversity-oriented synthesis of tricyclic indoles bearing 3,4fused seven-membered rings. Organic \& Biomolecular Chemistry, 2019, 17 (24), pp.5982-5989. 10.1039/C9OB01045A . hal-02193173

\section{HAL Id: hal-02193173 \\ https: / hal-udl.archives-ouvertes.fr/hal-02193173}

Submitted on 8 Jul 2020

HAL is a multi-disciplinary open access archive for the deposit and dissemination of scientific research documents, whether they are published or not. The documents may come from teaching and research institutions in France or abroad, or from public or private research centers.
L'archive ouverte pluridisciplinaire HAL, est destinée au dépôt et à la diffusion de documents scientifiques de niveau recherche, publiés ou non, émanant des établissements d'enseignement et de recherche français ou étrangers, des laboratoires publics ou privés. 


\title{
4-Aminoindoles as 1,4-bisnucleophiles for diversity-oriented synthesis of tricyclic indoles bearing
}

\section{3,4-fused seven-membered rings}

Shaomin Chen, ${ }^{\text {a }}$ Palanisamy Ravichandiran, ${ }^{\mathrm{a}}$ Ahmed El-Harairy, ${ }^{\mathrm{a}}$ Yves Queneau, ${ }^{\mathrm{c}}$ Minghao $\mathrm{Li}^{\mathrm{a}}$ and Yanlong $\mathrm{Gu}^{* a, b}$

a. Key Laboratory for Large-Format Battery Materials and System, Ministry of Education, School of Chemistry and Chemical Engineering, Huazhong University of Science and Technology, 430074, Wuhan, China. E-mail: klgyl@hust.edu.cn (Y.Gu)

b. State Key Laboratory for Oxo Synthesis and Selective Oxidation, Lanzhou Institute of Chemical Physics, 730000, Lanzhou, China.

c. Institut de Chimie et Biochimie Moléculaires et Supramoléculaires, Univ Lyon, CNRS, Université Lyon 1, INSA Lyon, CPE Lyon, ICBMS, UMR 5246; Université Claude Bernard, Bâtiment Lederer, 1 Rue Victor Grignard, 69622 Villeurbanne Cedex, France.

\begin{abstract}
A straightforward access to tricyclic indoles bearing 3,4-fused seven-membered ring has been established by using 4-aminoindoles as 1,4-bisnucleophiles in three-component reactions. $1 H$ Azepino[4,3,2-cd]indoles, 4,6-dihydro- $1 H$-azepino[4,3,2-cd]indoles and 1,3,4,6-tetrahydro-5Hazepino[4,3,2-cd] indol-5-ones could thus be synthesized in one-pot in moderate to good yields. Beyond opening access to 3,4-fused tricyclic indoles, the use of easily accessible 4-aminoindoles as C,N-1,4bisnucleophiles also provides a new platform to be used in a diversity-oriented synthesis strategy, fully displaying its benefits of maximizing molecular complexity and reaction diversity.
\end{abstract}

\section{Introduction}

The indole ring system is likely the most ubiquitous heterocycle in nature. ${ }^{1}$ The indole nucleus constitutes also the core unit of many therapeutic agents. ${ }^{2}$ Therefore, the ring construction and the structural decoration of indoles have attracted much attention in the past two decades. On the other hand, seven-membered ring system can often be found in the molecular structures of natural products and drug-related compounds. ${ }^{3}$ Organic and pharmaceutical chemists were therefore attracted by searching for efficient method for construct a seven-membered ring system. A special class of these compounds, namely tricyclic indole alkaloids bearing 3,4-fused seven-membered rings, are particularly important as these indole derivatives are characterized not only by interesting structural architectures but also sometime by unique biological 
activities. ${ }^{4}$ Communesin $\mathrm{F},{ }^{5}$ aurantioclavine, ${ }^{6}$ clavicipitic acid ${ }^{7}$ communesin $\mathrm{B},{ }^{8}$ cimitrypazepine, ${ }^{9}$ and fargesine ${ }^{10}$ are the representative examples. Because of their significant importance, much attention has been currently focused on the synthesis of tricyclic indole alkaloids bearing 3,4-fused seven-membered rings. Jia and Nemoto have developed some new synthetic methods, which facilitated the synthesis of such polycyclic indole alkaloids. ${ }^{11}$ Many other research groups have also been involved in this area. ${ }^{12}$ Despite much efforts have been paid in this area, the construction of a four-atom bridge between the C3 and C4 positions of indole is still a challenge.

1,4-Bisnucleuophiles have been often used for constructing heterocycles with a seven-membered ring, such as $o$-phenylenediamine, 2-aminobenzenethiol and 2-mercaptoacetamide. ${ }^{13} \mathrm{We}$ conjectured that 4 aminoindoles should be also potential 1,4-bisnucleophiles, based on the reactivities of both the C3unsubstituted indole and of the aromatic amine, and that they could be used for the synthesis of tricyclic indoles bearing a 3,4-fused seven-membered ring. 4-Aminoindoles benefit furthermore from being either commercially available or easily synthesized by hydrogenation of 4-nitroindoles. ${ }^{14}$ Most reactions of 4aminoindoles are based on the reactivity of the amino group, ${ }^{15}$ however the simultaneous use of both the amino group and the C3-postion of indole ring (as a 1,4-bisnucleophile) has been rarely documented. ${ }^{16} \mathrm{We}$ report herein, for the first time, the synthesis of tricyclic indoles bearing 3,4-fused seven-membered ring by reaction of 4-aminoindoles. This work showed that the use of 4-aminoindoles as 1,4-bisnucleophiles not only provided a straightforward way to construct tricyclic indoles otherwise difficult to prepare, but also extended to some extent the structural diversity of indole derivatives.

\section{Results and discussion}

The three-component reaction of 4-aminoindole 1a, diethyl acetylenedicarboxylate $\mathbf{2 a}$ and $p$-tolualdehyde 3a was investigated. This reaction was selected because dialkyl acetylenedicarboxylate was known to react with an amine to form a hydroamination product, ${ }^{17}$ which is a nucleophilic enamine, thus allowing some multicomponent reactions to be established. ${ }^{18}$ The hydroamination product $\mathbf{5 a}$ arising from dialkyl acetylenedicarboxylate and 4-aminoindole, if formed, might be able to trigger further domino reactions. Generation of the tricyclic indole derivative $\mathbf{5 b}$ from intermediate $\mathbf{5 a}$ was thus expected. However, compound $\mathbf{4 a}$, a dehydrogenative product of $\mathbf{5 b}$, was surprisingly isolated when $\mathrm{Cu}(\mathrm{OTf})_{2}$ was used as a catalyst and anhydrous ethanol as solvent at $60{ }^{\circ} \mathrm{C}$. The influence of catalyst and the solvent was investigated further, and the results were shown in Table 1 . After $6 \mathrm{~h}$, compound $\mathbf{4 a}$ was obtained in $87 \%$ yield (Table 1, entry 1). In the absence of catalyst, $\mathbf{4 a}$ could not be formed (entry 2). The use of Fe(OTf) 3 as a catalyst was also found to initiate the reaction, but the yield reached only $42 \%$ (entry 3 ). Two nonredox Lewis acids, namely $\mathrm{Al}(\mathrm{OTf})_{3}$ and $\mathrm{Sc}(\mathrm{OTf})_{3}$, were inefficient, leading to only trace amount of product (entries 4 and 5). Other $\mathrm{Cu}(\mathrm{II})$ salts were then examined in this reaction, but no reaction occurred using 
$\mathrm{Cu}(\mathrm{OAc})_{2}$ (entry 6), and most of the starting materials remained unchanged when $\mathrm{CuCl}_{2}$ and $\mathrm{CuBr}_{2}$ were used (entries 7 and 8). Performing the reaction under $\mathrm{O}_{2}$ atmosphere with an oxygen balloon did not improve the reaction yield (entry 9). However, removing molecular oxygen from the system resulted in a dramatic decrease in the reaction yield (entry 10). With respect to solvents that were screened, ethanol was clearly the most appropriate for the reaction (entries 11 to 15). Checking the influence of the amount of catalyst, temperature and reaction time, the optimal conditions were defined as $5 \mathrm{~mol} \%$ of $\mathrm{Cu}(\mathrm{OTf})_{2}, 60{ }^{\circ} \mathrm{C}$ and $6 \mathrm{~h}$ (entries 16 to 18). It should be noted that the reactions scaled up to multigram quantities provided uniform results. For example, the reaction of $\mathbf{1 a}(9 \mathrm{mmol}), \mathbf{2 a}(9 \mathrm{mmol})$ and $\mathbf{3 a}(6 \mathrm{mmol})$ in a $250 \mathrm{~mL}$ flask gave the desired product $\mathbf{4 a}$ in $86 \%$ yield (2.07 g, entry 19). To shed light on the reaction mechanism, several control experiments were conducted, and the results are given in Scheme 1. In the presence of lower catalyst amount ( $2 \mathrm{~mol} \%$ of $\mathrm{Cu}(\mathrm{OTf})_{2}$ ), heating an equimolar mixture of 1a, 2a and 3a in ethanol not only resulted in the formation of the expected product $\mathbf{4 a}$ but also led to the isolation of $\mathbf{5 a}$ (equation 1). In the absence of aldehyde, the hydroamination of $2 \mathbf{a}$ with $1 \mathbf{a}$ occurred smoothly at $40{ }^{\circ} \mathrm{C}$. The presence of the catalyst was not necessary, as $\mathbf{5 a}$ could be isolated in $87 \%$ yield after $6 \mathrm{~h}$ without adding $\mathrm{Cu}(\mathrm{OTf})_{2}$, whereas in the presence of $\mathrm{Cu}(\mathrm{OTf})_{2}$ catalyst, the yield of $\mathbf{5 a}$ reached only $78 \%$ (equation 2). Compound $\mathbf{5 a}$ can be converted to $4 \mathbf{a}$ in the presence of $\mathrm{Cu}(\mathrm{OTf})_{2}$. This reaction proceeded very fast at $60{ }^{\circ} \mathrm{C}$ under air in the presence of $\mathrm{Cu}(\mathrm{OTf})_{2}$. Most of 5a was consumed after 30 minutes, and the yield of $\mathbf{4 a}$ reached $63 \%$ (equation 3). However, in the absence of $\mathrm{Cu}(\mathrm{OTf})_{2}$, only tiny amount of $\mathbf{4 a}$ was formed. Performing the reaction of $\mathbf{1 a}, \mathbf{2 a}$, and $\mathbf{3 a}$ under argon atmosphere led to an inseparable mixture of $\mathbf{4 a}$ and $\mathbf{5 b}$ in a ca. 1/4 ratio based on careful analysis using ${ }^{1} \mathrm{H},{ }^{13} \mathrm{C}$ NMR and HRMS (equation 4).

On the basis of these results, a plausible mechanism was proposed. As depicted in the reaction equation in Table 1, the initial event of the reaction should be the hydroamination of $\mathbf{2 a}$ with $\mathbf{1 a}$, leading to the formation of the intermediate 5a. This compound behaves like a 1,6-bisnucleophile, and then can react with the aldehyde $\mathbf{3 a}$ under acidic conditions to give $\mathbf{5} \mathbf{b} .{ }^{19}$ Finally, the oxidative aromatization of $\mathbf{5 b}$ yields the final product 4a. The $\mathrm{Cu}(\mathrm{II})$ salt plays an important role in the last two steps. It should be noted that, during the reaction, an imine should also be formed by reaction between the amino group of $\mathbf{1 a}$ and the aldehyde group of 3a. But, the imine formation reaction being reversible, the hydroamination-triggered reaction sequence toward the formation of $\mathbf{4 a}$ became thus the predominant pathway in this process.

The scope of the substrates was then investigated and the results were shown in Scheme 2. Looking first at the scope of aldehydes, it was found that aldehydes $\mathbf{3}$ with different functional groups on the arene ring all worked well under the standard conditions, efficiently producing the corresponding 3,4-fused tricyclic indoles $\mathbf{4 b}-\mathbf{4 l}$ with yields ranging from $40 \%$ to $81 \%$. A variety of functional groups such as tert-butyl (4c), methoxy (4d and 4l), methylthio (4e), chloro (4f), bromo (4g), ethoxycarbonyl (4h), cyano (4i), nitro $(\mathbf{4 j})$, and trifluoromethyl $(\mathbf{4 k})$, were found to tolerate the $\mathrm{Cu}(\mathrm{II})$-promoted conditions well. The more sterically 
demanding $o$-anisaldehyde was also successfully engaged in this reaction, delivering product $\mathbf{4 l}$ in a fair $56 \%$ yield. The reaction with 2-naphthaldehyde proceeded also very well, providing the expected product $\mathbf{4 m}$ in $69 \%$ yield. Heterocyclic aromatic aldehydes such as furfural and 2-thenaldehyde were also applicable in the reaction, the heterocyclic groups could be delivered into the products $4 \mathbf{n}$ and $4 \mathbf{0}$ without any damage. Our attempts to use aliphatic aldehydes were also successful. For example, the reaction of 3-phenylpropanal with 1a and 2a led to compound $\mathbf{4 p}$ in $43 \%$ yield. Cyclopropanecarboxaldehyde, despite being acid-labile, was found to be applicable in the reaction, providing the expected product $\mathbf{4 q}$ in $58 \%$ yield. Next, we evaluated the influence of the electronic nature of the indole ring. Different substituents, such as fluoro, chloro and methoxycarbonyl, located at the 6-position were applicable in the three-component process leading to the corresponding 3,4-fused tricyclic indoles $\mathbf{4 r}-\mathbf{4 t}$ in $34 \%-52 \%$ yields. 4-Amino- $\mathrm{N}$ methylindole is also a 1,4-bisnucleophile able to react with $\mathbf{2 a}$ and $\mathbf{3 a}$ leading to $\mathbf{4} \mathbf{u}$. With respect to the alkyne partner, efficient reaction of dimethyl acetylenedicarboxylate with $\mathbf{1 a}$ and $\mathbf{3 a}$ confirmed the results observed in Table 1, leading to the expected product $\mathbf{4 v}$ in $66 \%$ yield. Methyl propiolate can also be used instead of $\mathbf{2 a}$, and the reaction provided the 3,4-fused tricyclic indole derivative $\mathbf{4 w}$ in $53 \%$ yield. Obviously, the present three-component reaction is compatible with a wide range of structurally distinct substrates varying in steric hindrance and electronic properties, and provides therefore an efficient and practical protocol for assembling richly decorated 3,4-fused tricyclic indoles with high efficiency.

Studying further whether substrate $\mathbf{2 a}$ could be substituted in the above-mentioned reaction, we found that it could be uneventfully replaced by ethyl acetopyruvate $\mathbf{6 a}$. Theoretically speaking two products could be formed because the two keto-carbonyl groups in $\mathbf{6 a}$ are both able to condense with the amino group of 1a. However, only one product $\mathbf{4 x}$, arising from the condensation of the $\alpha$-carboxy ketone, was detected and isolated in the reaction (Scheme 3). It is reasonable because the adjacent ester group makes the middle keto-carbonyl more electron-deficient than the terminal ketone. We failed to use more common linear 1,3dicarbonyl compounds, such as methyl acetoacetate and acetylacetone, in the three-component reaction. These results imply that, to build a bridge between the $\mathrm{C} 3$ and $\mathrm{C} 4$ positions starting from $\mathbf{1 a}$ and an aldehyde, the dual electrophilic/nucleophilic component should possess a highly active electrophilic site. This appears indispensable for initiating the reaction by condensation of this with the amino group of 1a, which is the most reactive part of the 1,4-bisnucleophile, to form the intermediate that can be further trapped by the aldehyde thus driving the whole process.

On the basis of this understanding, we tried to use 1,3-cyclohexanediones as they possess much higher reactivities than linear 1,3-dicarbonyl compounds due to the predominance of the 
enol forms in many conditions. ${ }^{20}$ The reaction of dimedone $\mathbf{6 b}$ with $\mathbf{1 a}$ and $\mathbf{3 a}$ proceeded smoothly in the presence of catalytic amount of potassium hydroxide. And, after $6 \mathrm{~h}$ in 1,4-dioxane, a 2,6,7,8,9,11hexahydro-10H-benzo[6,7]azepino[4,3,2-cd]indol-10-one derivative 7a was isolated in 55\% yield (Scheme 4). Benzaldehydes with either electron-donating or electron-withdrawing groups were both able to assemble with $1 \mathbf{a}$ and dimedone $\mathbf{6 b}$. The reaction of $\mathbf{1 a}, \mathbf{3 a}$ and 1,3-cyclohexadione $\mathbf{6 c}$ proceeded also very well, affording the desired product $\mathbf{7 d}$ in 53\% yield. Unlike, 1,3-pentanedione and 1,3-indanedione failed to react in this three-component reaction. An electron-rich 1,4- bisnucleophile, 4-amino-1-methylindole, can also be used to react with $\mathbf{3 a}$ and $\mathbf{6 b}$, leading to the expected product $\mathbf{7 e}$ in $59 \%$ yield (Scheme 4).

Intriguingly, acetone was found to be able to react with $\mathbf{1 a}$ and $\mathbf{3 a}$ in presence of $\mathrm{Fe}(\mathrm{OTf})_{3}$ as catalyst in 1,4-dioxane at $80{ }^{\circ} \mathrm{C}$, leading to compound $4 \mathbf{y}$ in $78 \%$ yield after $6 \mathrm{~h}$ of reaction (Scheme 5). By using $\mathrm{Cu}(\mathrm{OTf})_{2}$ as a catalyst, the reaction proceeded sluggishly under the same conditions, affording $4 \mathbf{y}$ only in $19 \%$ yield. Cyclic ketones, such cyclopentanone, cyclohexanone, and cycloheptanone were also found to be applicable in this reaction, and the expected products $\mathbf{4 z}$, 4aa and $4 \mathbf{a c}$ were isolated in 64\%, 68\% and $53 \%$ yields, respectively. Tetrahydro-4H-pyran-4-one was proven to be able to react with $\mathbf{1 a}$ and $\mathbf{3 a}$, and the expected product $\mathbf{4 a b}$, with its ether unaffected functionality, was isolated in $80 \%$ yield (Scheme 5). Acetophenone failed to produce the corresponding product 4ad due to the extensive formation of 1,3,5triphenylbenzene. Fortunately, the expected products could be reached through a Fe(OTf) 3 -catalyzed twocomponent reaction of $\mathbf{1 a}$ and chalcone (Scheme 6). This offered thus an alternative way to access these tricyclic indoles bearing 3,4-fused seven-membered rings.

Finally, the three-component reaction of $\mathbf{1 a}$ and 3a with Meldrum's acid proceeded also very well in acetonitrile under catalyst-free conditions. After $3 \mathrm{~h}$ at $60{ }^{\circ} \mathrm{C}$, a 1,3,4,6-tetrahydro-5H-azepino[4,3,2cd]indol-5-one derivative 8a was obtained in 76\% yield (Scheme 7). Mechanistically, the three molecules assembled through a tandem Knoevenagel/Michael addition/intramolecular amidation reaction, producing 8a as the final product while eliminating $\mathrm{CO}_{2}$ and acetone as by-products. ${ }^{21}$ Such compounds containing this 1,3,4,6-tetrahydro-5H-azepino[4,3,2-cd]indol-5-one skeleton exhibit interesting biologically activities. ${ }^{22}$ However, the reported methods to establish this skeleton either require delicate multistep synthesis or rely heavily on the use of a noble metal catalyst. ${ }^{23}$ The present reaction thus offers a useful and straightforward way to access these molecules.

\section{Conclusions}

4-Aminoindoles were proved to be reactive $\mathrm{C}, \mathrm{N}-1,4$-bisnucleophiles which can easily react with appropriate electrophiles, such as aldehydes and $\alpha, \beta$-unsaturated compounds, to form various tricyclic indoles bearing 3,4-fused seven-membered ring. This being established, the three-component reaction was employed in a diversity-oriented synthesis strategy. Novel $1 \mathrm{H}$-azepino[4,3,2-cd]indoles, 4,6-dihydro-1H- 
azepino[4,3,2-cd]indoles and 1,3,4,6-tetrahydro-5H-azepino[4,3,2-cd]indol-5-ones were thus synthesized in a straightforward way. This work also encourages organic chemists to explore valuable modular synthons outside of their known use, and by combination of the hitherto unreported reactivity together with an appropriate amenability to known transformations, some new reactions can be developed in a fast and efficient manner.

\section{Experimental - General experimental methods}

All reagents were purchased from commercial suppliers and used without further purification. The reactions were monitored by TLC with Haiyang GF-254 silica gel plates (Qingdao Haiyang chemical industry Co. Ltd, Qingdao, China) using UV light or $\mathrm{KMnO}_{4}$ as visualizing agents as needed. The preparative TLC plates were made by ourselves, and the thickness is about $2 \mathrm{~mm}$. Flash column chromatography was performed using 200-300 mesh silica gel at increased pressure. ${ }^{1} \mathrm{H}$ NMR spectra and ${ }^{13} \mathrm{C}$ NMR spectra were respectively recorded on Brüker AV-400 spectrometers. Chemical shifts $(\delta)$ were expressed in ppm relative to $\mathrm{Me}_{4} \mathrm{Si}$ in $\mathrm{CDCl}_{3}$ or DMSO- $d_{6}$, and coupling constants $(J)$ were reported in Hz. High-resolution mass spectra (HRMS) were obtained on Brüker Compass Data Analysis 4.0. IR spectra were recorded on a Bruker FT-IR (EQUINOX 55) using KBr pellets or neat liquid technology.

General procedure for the reaction of 4-aminoindoles, alkynes and aldehydes. The reactions were carried out in a $10 \mathrm{~mL} \mathrm{~V}$-type single-neck flask equipped with oil bath and triangle magnetic stirring bar. In the flask, $1 \mathbf{a}(0.3 \mathrm{mmol})$ was mixed under air with $\mathbf{2 a}(0.3 \mathrm{mmol}), \mathbf{3 a}(0.2 \mathrm{mmol})$, and $\mathrm{Cu}(\mathrm{OTf})_{2}(0.01$ $\mathrm{mmol}, 5 \mathrm{~mol} \%)$ in anhydrous ethanol $(1.0 \mathrm{~mL})$, and the mixture was then stirred at $60{ }^{\circ} \mathrm{C}$ for $6 \mathrm{~h}$. After completion of the reaction, the mixture was cooled to room temperature, and then subjected to preparative TLC by using a mixture of petroleum ether and ethyl acetate as eluent $\left(\mathrm{PE} / \mathrm{EA}=4 / 1_{\mathrm{v} / \mathrm{v}}\right)$. Experiments for the substrate scope were all performed with an analogous procedure.

Procedure for the synthesis of $4 \mathbf{a}$ in $6 \mathbf{~ m m o l ~ s c a l e . ~ C o m p o u n d ~} 1 \mathbf{a}(9.0 \mathrm{mmol})$ was mixed with $\mathbf{2 a}(9.0$ $\mathrm{mmol}), 3 \mathbf{a}(6.0 \mathrm{mmol}), \mathrm{Cu}(\mathrm{OTf})_{2}(0.3 \mathrm{mmol}, 5 \mathrm{~mol} \%)$ and ethanol $(30 \mathrm{~mL})$ in a $250 \mathrm{~mL}$ of round bottomed flask equipped with oil bath and magnetic stirring. The mixture was then stirred at $60{ }^{\circ} \mathrm{C}$ for $6 \mathrm{~h}$. After completion of the reaction, brine $(50 \mathrm{~mL})$ was added. And then, the aqueous phase was extracted by ethyl acetate $(30 \mathrm{~mL} \times 3)$. The acquired organic phase was dried by anhydrous $\mathrm{Na}_{2} \mathrm{SO}_{4}$. After removing the volatile components, the organic residue was subjected to silica column chromatography (eluent: petroleum ether / ethyl acetate $=4 / 1(\mathrm{v} / \mathrm{v}))$. Compound 4 a was obtained in $86 \%$ yield $(2.07 \mathrm{~g})$. 
Procedure for the synthesis of $\mathbf{4 x}$. The reactions were carried out in a $10 \mathrm{~mL}$ V-type single-neck flask equipped with oil bath and triangle magnetic stirring bar. In the flask, 1a $(0.2 \mathrm{mmol})$ was mixed with 3a $(0.2 \mathrm{mmol}), 6 \mathbf{a}(0.6 \mathrm{mmol})$, and $\mathrm{Cu}(\mathrm{OTf})_{2}(0.01 \mathrm{mmol}, 5 \mathrm{~mol} \%)$ in ethanol $(1.0 \mathrm{~mL})$, and the mixture was then stirred at $60{ }^{\circ} \mathrm{C}$ for $6 \mathrm{~h}$. After completion of the reaction, the mixture was cooled to room temperature, and then subjected to preparative TLC by using a mixture of petroleum ether and ethyl acetate as eluent $\left(\mathrm{PE} / \mathrm{EA}=4 / 1_{\mathrm{v} / \mathrm{v}}\right)$. Compound $\mathbf{4 x}$ was obtained in $55 \%$ yield $(40.9 \mathrm{mg})$.

\section{General procedure for the reaction of 4-aminoindoles, aromatic aldehydes and 1,3-} cyclohexanediones. The reactions were carried out in a $10 \mathrm{~mL}$ single-neck V-type flask equipped with oil bath and triangle magnetic stirring bar. In the flask, $\mathbf{1 a}(0.2 \mathrm{mmol})$ was mixed with $\mathbf{3 a}(0.22 \mathrm{mmol}), \mathbf{6 b}$ $(0.22 \mathrm{mmol})$, and $\mathrm{KOH}(0.01 \mathrm{mmol}, 5 \mathrm{~mol} \%)$ in 1,4-dioxane $(1.0 \mathrm{~mL})$, and the mixture was then stirred at $60{ }^{\circ} \mathrm{C}$ for $6 \mathrm{~h}$. After completion of the reaction, the mixture was cooled to room temperature, and then subjected to preparative TLC by using a mixture of petroleum ether and ethyl acetate as eluent (PE/EA = $\left.4 / 1_{\mathrm{v} / \mathrm{v}}\right)$. Experiments for the substrate scope were all performed with an analogous procedure.

General procedure for the reaction of 4-aminoindole, $p$-tolualdehyde and ketones. The reactions were carried out in a single-neck $10 \mathrm{~mL} \mathrm{~V}$-type flask equipped with oil bath and triangle magnetic stirring bar. In the flask, 1a $(0.3 \mathrm{mmol})$ was mixed with $\mathbf{3 a}(0.2 \mathrm{mmol})$, acetone $(0.3 \mathrm{mmol})$, and $\mathrm{Fe}(\mathrm{OTf})_{3}(0.02 \mathrm{mmol}$, $10 \mathrm{~mol} \%)$ in 1,4-dioxane $(1.0 \mathrm{~mL})$, and the mixture was then stirred at $80^{\circ} \mathrm{C}$ for $6 \mathrm{~h}$. After completion of the reaction, the mixture was cooled to room temperature, and then subjected to preparative TLC by using a mixture of petroleum ether and ethyl acetate as eluent $\left(P E / E A=4 / 1_{v / v}\right)$. Experiments for the substrate scope were all performed with an analogous procedure.

Procedure for the synthesis of 4ad. The reactions were carried out in a single-neck $10 \mathrm{~mL}$ V-type flask equipped with oil bath and triangle magnetic stirring bar. In a typical reaction, $1 \mathbf{a}(0.3 \mathrm{mmol})$ was mixed with chalcone $(0.3 \mathrm{mmol})$, and $\mathrm{Fe}(\mathrm{OTf})_{3}(0.03 \mathrm{mmol}, 10 \mathrm{~mol} \%)$ in 1,4-dioxane $(1.0 \mathrm{~mL})$, the mixture was then stirred at $60{ }^{\circ} \mathrm{C}$ for $6 \mathrm{~h}$. After completion of the reaction, the mixture was cooled to room temperature, and then subjected to preparative TLC by using a mixture of petroleum ether and ethyl acetate as eluent $\left(\mathrm{PE} / \mathrm{EA}=4 / 1_{\mathrm{v} / \mathrm{v}}\right)$. Compound 4 ad was obtained in $47 \%$ yield $(45.1 \mathrm{mg})$.

Procedure for the synthesis of 8a. The reactions were carried out in a single-neck $10 \mathrm{~mL}$ V-type flask equipped with oil bath and triangle magnetic stirring bar. In the flask, $1 \mathbf{a}(0.3 \mathrm{mmol})$ was mixed with 3a $(0.3 \mathrm{mmol})$, and Meldrum's acid $(0.3 \mathrm{mmol})$ in acetonitrile $(1.0 \mathrm{~mL})$, and the mixture was then stirred at 60 ${ }^{\circ} \mathrm{C}$ for $3 \mathrm{~h}$. After completion of the reaction, the mixture was cooled to room temperature, and then subjected 
to preparative TLC by using a mixture of petroleum ether and ethyl acetate as eluent $\left(\mathrm{PE} / \mathrm{EA}=4 / 1_{\mathrm{v} / \mathrm{v}}\right)$. Compound $8 \mathbf{a}$ was obtained in $76 \%$ yield $(63.0 \mathrm{mg})$.

\section{Conflicts of interest}

There are no conflicts to declare.

\section{Acknowledgements}

We thank the National Natural Science Foundation of China for financial support (2171101076 and 21872060). We are grateful to the Analytical and Testing Centre of HUST. The Cooperative Innovation Center of Hubei Province is also acknowledged.

\section{Notes and references}

1 (a) D. A. Horton, G. T. Bourne and M. L. Smythe, Chem. Rev., 2003, 103, 893; (b) M. Petrini, Chem. -Eur. J., 2017, 23, 16115; (c) M. Shiri, Chem. Rev., 2012, 112, 3508; (d) M. Shiri, M. A. Zolfigol, H. G. Kruger and Z. Tanbakouchian, Chem. Rev., 2010, 110, 2250; (e) Y. Gu, W. Huang, S. Chen and X. Wang, Org. Lett., 2018, 20, 4285.

2 (a) C. Buvana, R. Suresh, Y. Haribabu and P. K. Manna, World J. Pharm. Res., 2018, 7, 1; (b) P. Konopelski and M. Ufnal, Curr. Drug Metab., 2018, 19, 883; (c) D. Goyal, A. Kaur, and B. Goyal, ChemMedChem, 2018, 13, 1275; (d) J. Yang, F. Mei, S. Fu and Y. Gu, Green Chem., 2018, 20, 1367.

3 (a) J. B. Bremner and S. Samosorn, Comprehensive Heterocyclic Chemistry, Elsevier, 2008, 13, 1;

(b) J. J. Vaquero, A. M. Cuadro and B. Herradón, Modern Heterocyclic Chemistry (Eds.: J, AlvarezBuilla, J. J. Vaquero, J. Barluenga), Wiley-VCH, Weinheim, 2011, pp. 1865.

4 (a) T. Nemoto, S. Harada and M. Nakajima, Asian J. Org. Chem., 2018, 7, 1730; (b) M. G. Ciulla, S. Zimmermann and K. Kumar, Org. Biomol. Chem., 2019, 17, 413; (c) Y. Wang, F. Xie, B. Lin, M. Cheng and Y. Liu, Chem -Eur. J., 2018, 24, 14302.

5 (a) S. P. Lathrop, M. Pompeo, W.-T. T. Chang and M. Movassaghi, J. Am. Chem. Soc., 2016, 138, 7763; (b) J. Belmar and R. L. Funk, J. Am. Chem. Soc., 2012, 134, 16941; (c) Z. Zuo, W. Xie, D. Ma, J. Am. Chem. Soc., 2010, 132, 13226; (d) J. Yang, H. Wu, L. Shen and Y. Qin, J. Am. Chem. Soc., 2007, 129, 13794.

6 (a) K. Brak and J. A. Ellman, Org. Lett., 2010, 12, 2004; (b) J. Park, D. -H. Kim, T. Das and C. -G. Cho, Org. Lett., 2016, 18, 5098; (c) S. Suetsugu, H. Nishiguchi, C. Tsukano and Y. Takemoto, Org. Lett., 2014, 16, 996; (d) Z. Xu, W. Hu, Q. Liu, L. Zhang and Y. Jia, J. Org. Chem., 2010, 75, 7626; 
(e) K. Yamada, Y. Namerikawa, T. Haruyama, Y. Miwa, R. Yanada and M. Ishikura, Eur. J. Org. Chem., 2009, 5752.

7 (a) M. Ito, Y. -K. Tahara and T. Shibata, Chem. -Eur. J., 2016, 22, 5468; (b) F. Bartoccini, M. Casoli, M. Mari and G. Piersanti, J. Org. Chem., 2014, 79, 3255; (c) Q. Liu, Q. Li, Y. Ma and Y. Jia, Org. Lett., 2013, 15, 4528; (d) J. -M. Ku, B. -S. Jeong, S. -S. Jew and H. -G. Park, J. Org. Chem., 2007, 72, 8115.

8 (a) T. V. Antipova, V. P. Zhelifonova, B. P. Baskunov, G. A. Kochkina, S. M. Ozerskaya and A. G. Kozlovskii, Microbiology, 2018, 87, 642; (b) H. -C. Lin, G. Chiou, Y. -H. Chooi, T. C. McMahon, W. Xu, N. K. Garg and Y. Tang, Angew. Chem. Int. Ed., 2015, 54, 3004.

9 G. Ghimire and B. C. G. Söderberg, Tetrahedron Lett., 2016, 57, 3873.

10 (a) Y. Tanaka, Y. Suzuki, Y. Hamada and T. Nemoto, Heterocycles, 2017, 95, 243; (b) D. Shan, Y. Gao and Y. Jia, Angew. Chem. Int. Ed., 2013, 52, 4902; (c) Y. Gao, D. Shan and Y. Jia, Tetrahedron, 2014, 70, 5136.

11 See two recent reviews: (a) L. Li, Z. Chen, X. Zhang and Y. Jia, Chem. Rev., 2018, 118, 3752; (b) T. Nemoto, Chem. Rec., 2019, 19, 320. See some elected examples from Jia's and Nemoto's groups: (c) Y. Suzuki, Y. Tanaka, S.-I. Nakano, K. Dodo, N. Yoda, K. -I. Shinohara, K. Kita, A. Kaneda, M. Sodeoka, Y. Hamada and T. Nemoto, Chem. -Eur. J., 2016, 22, 4418; (d) S. -I. Nakano, N. Inoue, Y. Hamada and T. Nemoto, Org. Lett., 2015, 17, 2622-2625; (e) P. Tao and Y. Jia, Chem. Commun., 2014, 50, 7367.

12 (a) S. P. Breazzano, Y. B. Poudel and D. L. Boger, J. Am. Chem. Soc., 2013, 135, 1600; (b) H. Shimamura, S. P. Breazzano, J. Garfunkle, F. S. Kimball, J. D. Trzupek and D. L. Boger, J. Am. Chem. Soc., 2010, 132, 7776; (c) T. Miura, Y. Funakoshi and M. Murakami, J. Am. Chem. Soc., 2014, 136, 2272; (d) X. Zhang, Y. Li, H. Shi, L. Zhang, S. Zhang, X. Xu and Q. Liu, Chem. Commun., 2014, 50, 7306.

13 (a) C. Li, Q. Zhang and X. Tong, Chem. Commun., 2010, 46, 7828; (b) S. Chimichi, M. Boccalini, S. Selleri, C. Costagli, G. Guerrini and G. Viola, Org. Biomol. Chem., 2008, 6, 739; (c) T. A. Ioannou, P. A. Koutentis, H. Krassos, G. Loizou and D. Lo Re, Org. Biomol. Chem., 2012, 10, 1339; (d) T. -H. Zhu, S. -Y. Wang, G. -N. Wang and S. -J. Ji, Chem. -Eur. J., 2013, 19, 5850; (e) Y. Wang, M. -S. Tu, F. Shi and S. -J. Tu, Adv. Synth. Catal., 2014, 356, 2009; (f) J. M. Khurana, A. Chaudhary, A. Lumb and B. Nand, Green Chem., 2012, 14, 2321; (g) A. Shaabani, S. E. Hooshmand, M. T. Nazeri, R. Afshari and S. Ghasemi, Tetrahedron Lett., 2016, 57, 3727; (h) G. Choudhary and R. K. Peddinti, Green Chem., 2011, 13, 3290; (i) C. Wu, L. Hong, H. Shu, Q. -H. Zhou, Y. Wang, N. Su, S. Jiang, Z. Cao, W. -M. He, ACS Sustainable Chem. Eng. 2019, 7, 8798. 
14 (a) S. Furukawa, Y. Yoshida and T. Komatsu, ACS Catal., 2014, 4, 1441; (b) L. -Y. Li, H. -X. Zhao, J. -Y. Wang and R. -H. Wang, ACS Nano, 2014, 8, 5352; (c) L. -Y. Li, Z. -L. Chen, H. Zhong and R. -H. Wang, Chem. -Eur. J., 2014, 20, 3050; (d) G. -Q. Chen, W. -B. Gao, X. -J. Wang and H. -F. Huo, RSC Adv., 2016, 6, 58805; (e) P. -F. Ji, K. Manna, Z. -K. Lin and X. -Y. Feng, J. Am. Chem. Soc., 2017, 139, 7004; (f) Y. -J. Ding, C. -Y. Li, J. -J. Chen and J. -H. Zeng, Adv. Synth. Catal., 2017, 359, 2280; (g) S. Doherty, J. G. Knight, T. Backhouse and A. Bradford, Catal. Sci. Technol., 2018, 8, 1454.

15 (a) M. Somei and M. Tsuchiya, Chem. Pharm. Bull., 1981, 29, 3145; (b) N. Mahindroo, M. C. Connelly, C. Punchihewa, L. Yang, B. Yan and N. Fujii, Bioorg. Med. Chem., 2010, 18, 4801; (c) Y. Cui, S. Kwok, A. Bucholtz, B. Davis, R. A. Whitney and P. G. Jessop, New J. Chem., 2008, 32, 1027; (d) W. Xun, B. Xu, B. Chen, S. Meng, A. S. C. Chan, F. G. Qiu and J. Zhao, Org. Lett., 2018, 20, 590; (e) T. Vacala, L. P. Bejcek, C. G. Williams, A. C. Williamson and P. A. Vadola, J. Org. Chem., 2017, 82, 2558; (f) Y. -Y. Ding, D. -F. Xu, S. -S. Meng, Y. Li and J. -L. Zhao, Adv. Synth. Catal., 2018, 360, 664; (g) W. Zhai, B. Li and B. Wang, Tetrahedron, 2018, 74, 1123; (h) J. Zhou, B. Li, F. Hu and B. -F. Shi, Org. Lett., 2013, 15, 3460.

16 O. Halaiev, M. Garazd, A. Gzella and R. Lesyk, Tetrahedron Lett., 2017, 58, 1324.

17 (a) H. Imoto, K. Nohmi, K. Kizaki, S. Watase, K. Matsukawa, S. Yamamoto, M. Mitsuishi and K. Naka, RSC Adv., 2015, 5, 94344; (b) D. Ramanathan and K. Pitchumani, Eur. J. Org. Chem., 2015, 2015, 463; (c) W. Wu, Y. Guo, X. Xu, Z. Zhou, X. Zhang, B. Wu and W. Yi, Org. Chem. Front., 2018, 5, 1713; (d) Q. Zhu, H. Jiang, J. Li, M, Zhang, X. Wang and C. Qi, Tetrahedron, 2009, 65, 4604.

18 (a) Q. -Y. Zhang, B. -K. Liu, W. -Q. Chen, Q. Wu and X. -F. Lin, Green Chem., 2008, 10, 972; (b) J. Sun, E. -Y. Xia, Q. Wu and C. -G. Yan, Org. Lett., 2010, 12, 3678; (c) S. V. H. S. Bhaskaruni, S. Maddila, W. E. van Zyl and S. B. Jonnalagadda, Catal. Commun., 2017, 100, 24; (d) S. Li, Q. Yang and J. Wang, Tetrahedron Lett., 2016, 57, 4500; (e) A. Rezvanian, Tetrahedron, 2016, 72, 6428; (f) S. Tabassum, S. Govindaraju, R. -R. Khan and M. A. Pasha, RSC Adv., 2016, 6, 29802; (g) A. B. Atar, J. S. Kim, K. T. Lim and Y. T. Jeong, New J. Chem., 2015, 39, 396.

19 See a review on the reactions of 1,6-bisnucleophiles: (a) V. N. Charushin, O. N. Chupakhin and H. C. Van Der Plas, Adv. Heterocycl. Chem., 1988, 43, 301. See some reactions of 1,6-bisnucleophiles with aldehyde or ketone: (b) L. Min, B. Pan and Y. Gu, Org. Lett., 2016, 18, 364; (c) M. Wang, C. Liu and Y. Gu, Tetrahedron, 2016, 72, 6854.

20 (a) J. M. Khurana, A. Chaudhary, A. Lumb and B. Nand, Green Chem., 2012, 14, 2321; (b) M. Nassiri, J. Heterocyclic Chem., 2014, 51, 1634; (c) F. M. Moghaddam, Z. Mirjafary , M. J. Javan and S. Motamen, Tetrahedron Lett., 2014, 55, 2908; (d) T. -W. Chung, B. D. Narhe, C. -C. Lin and 
C. -M. Sun, Org. Lett., 2015, 17, 5368; (e) F. Shirini, M. S. N. Langarudi, M. Seddighi and O. G. Jolodar, Res. Chem. Intermed., 2015, 41, 8483; (f) S. Nagaraju, K. Divakar, B. Paplal and D. Kashinath, New J. Chem., 2017, 41, 8993; (g) Y. -W. Sun and L. -Z. Wang, New J. Chem., 2018, 42, 20032; (h) W. Huang, J. Xu, C. Liu, Z Chen and Y. Gu, J. Org. Chem., 2019, 84, 2941; (i) W. Huang, S. Chen, Z. Chen, M. Yue, M. Li, Y. Gu, J. Org. Chem., 2019, 84, 5655; (k) J. Yang, X. Wang, A. El-Harairy, R. Bai, Y. Gu, Mol. Catal. 2019, 468, 36; (1) M. Li, F.Wu, Y. Gu, Chin. J. Catal. 2019, DOI: S1872-2067(19)63370-X.

21 B. Zou, C. Chen, S. Y. Leong, M. Ding and P. W. Smith, Tetrahedron, 2014, 70, 578.

22 (a) I. M. Bell, C. A. Stump, C. R. Theberge, S. N. Gallicchio, C. B. Zartman and H. G. Selnick, PCT Int. Appl., 2007, WO 2007061692 A2; (b) I. Bell and C. A. Stump, PCT Int. Appl., 2008, WO 2008153852 A1.

23 (a) W. J. Hoekstra, M. N. Greco, L. R. Hecker, B. Maryanoff and J. M. Matthews, PCT Int. Appl., 2000, WO 2000078762 A1; (b) T. Nagasaka and S. Ohki, Chem. Pharm. Bull., 1977, 25, 3023.

Table 1 Three-component reaction of indole (1a), diethyl acetylenedicarboxylate (2a) and p-tolualdehyde $(\mathbf{3 a})^{a}$

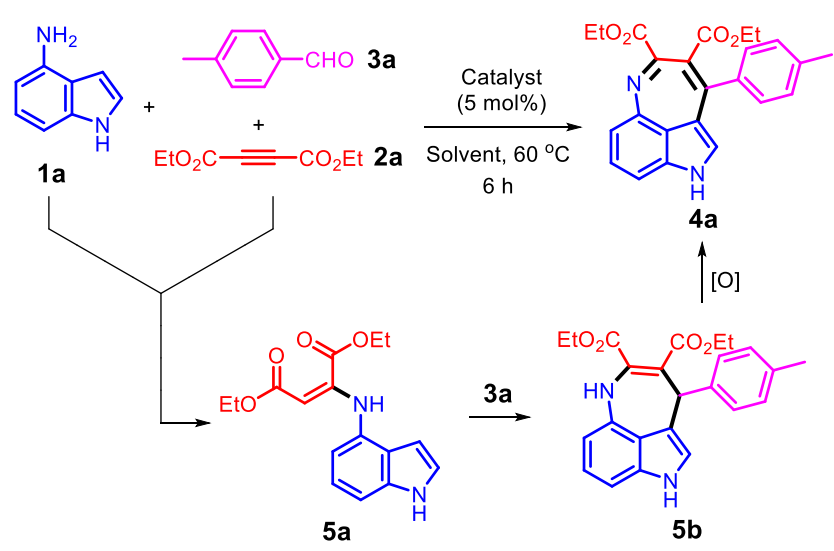

\begin{tabular}{llll}
\hline Entry & Catalyst & Solvent & Yield $(4 \mathrm{a}, \%)^{b}$ \\
\hline 1 & $\mathrm{Cu}(\mathrm{OTf})_{2}$ & EtOH & 87 \\
2 & - & EtOH & 0 \\
3 & $\mathrm{EtOH}$ & 42 \\
4 & $\mathrm{Fe}(\mathrm{OTf})_{3}$ & EtOH & $<5$ \\
5 & $\mathrm{Al}(\mathrm{OTf})_{3}$ & EtOH & $<5$
\end{tabular}




$\begin{array}{llll}6 & \mathrm{Cu}(\mathrm{OAc})_{2} & \text { EtOH } & 0 \\ 7 & \mathrm{CuCl}_{2} & \text { EtOH } & 14 \\ 8 & \mathrm{CuBr}_{2} & \text { EtOH } & 18 \\ 9 & \mathrm{Cu}(\mathrm{OTf})_{2} & \text { EtOH } & 88^{c} \\ 10 & \mathrm{Cu}(\mathrm{OTf})_{2} & \text { EtOH } & 53^{d} \\ 11 & \mathrm{Cu}(\mathrm{OTf})_{2} & \text { Acetonitrile } & 0 \\ 12 & \mathrm{Cu}(\mathrm{OTf})_{2} & 1,4-\text { Dioxane } & 31 \\ 13 & \mathrm{Cu}(\mathrm{OTf})_{2} & \text { Toluene } & 0 \\ 14 & \mathrm{Cu}(\mathrm{OTf})_{2} & \text { AcOH } & 0 \\ 15 & \mathrm{Cu}(\mathrm{OTf})_{2} & - & 0 \\ 16^{e} & \mathrm{Cu}(\mathrm{OTf})_{2} & \text { EtOH } & 62 \\ 17^{f} & \mathrm{Cu}(\mathrm{OTf})_{2} & \text { EtOH } & 42 \\ 18^{g} & \mathrm{Cu}(\mathrm{OTf})_{2} & \text { EtOH } & 45 \\ 19^{h} & \mathrm{Cu}(\mathrm{OTf})_{2} & \text { EtOH } & 86\end{array}$

${ }^{a}$ Reaction conditions: 1a, $0.3 \mathrm{mmol}$; 2a, $0.3 \mathrm{mmol}$; 3a, $0.2 \mathrm{mmol}$; catalyst, $0.01 \mathrm{mmol}$; solvent, $1 \mathrm{~mL}$; $60{ }^{\circ} \mathrm{C} ; 6$ h. ${ }^{b}$ Isolated yield. ${ }^{c}$ With an oxygen balloon. ${ }^{d}$ With a nitrogen balloon. ${ }^{e} \mathrm{Cu}(\mathrm{OTf})_{2}, 0.005 \mathrm{mmol}$. ${ }^{f} 40{ }^{\circ} \mathrm{C} .{ }^{g} 3 \mathrm{~h} .{ }^{h}$ The reaction was performed in a $6 \mathrm{mmol}$ scale in a $250 \mathrm{~mL}$ single-neck flask. 
<smiles>Nc1cccc2[nH]ccc12</smiles>

$1 \mathrm{a}$

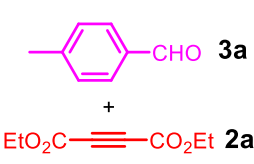

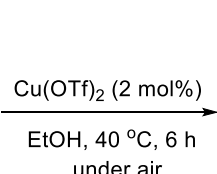

under air

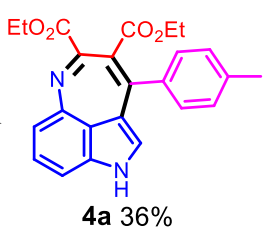

Aa $36 \%$

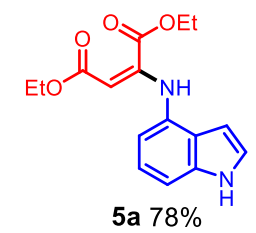

In the absence of $\mathrm{Cu}(\mathrm{OTf})_{2}, 87 \%$

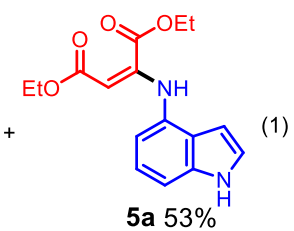

(2)

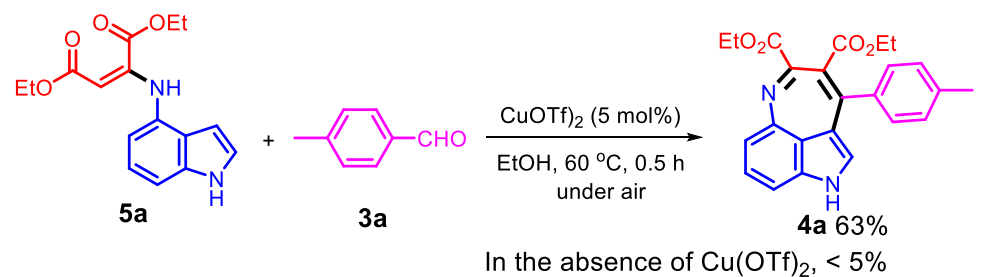

(3)
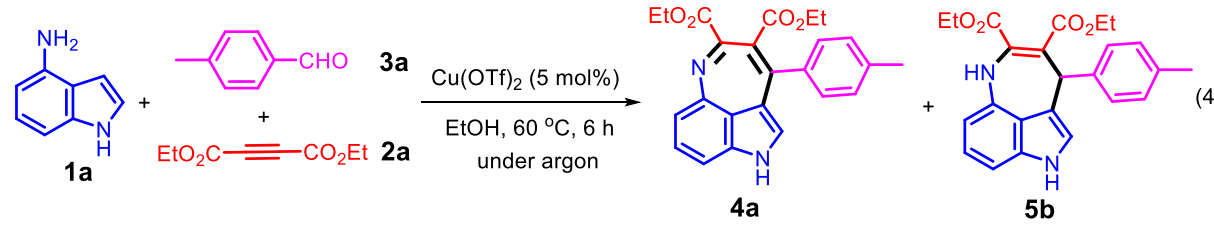

Total yield: $89 \%, \mathbf{4 a} / \mathbf{5 b}=1 / 4$

Scheme 1 Control experiments. 

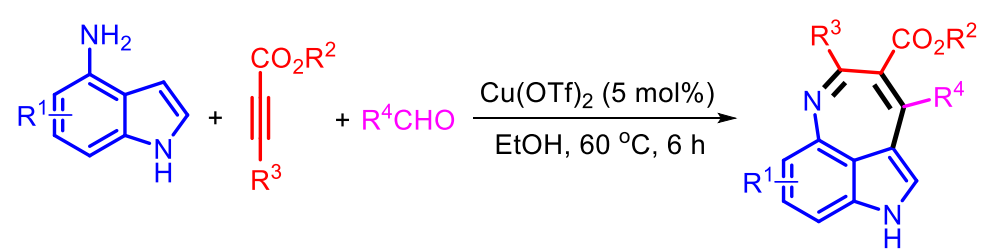
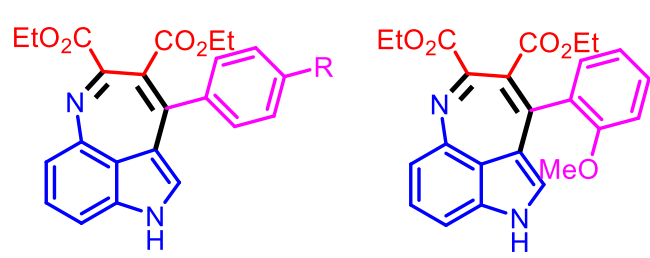

4I $56 \%$

4b $\mathrm{R}=\mathrm{H} 54 \%$
4c $\mathrm{R}=\mathrm{Bu}^{t} 61 \%$

4d $\mathrm{R}=\mathrm{OMe} 70 \%$

4e $\mathrm{R}=\mathrm{SMe} 62 \%$

4f $\mathrm{R}=\mathrm{Cl} 68 \%$

4g R $=\mathrm{Br} 53 \%$

4h $\mathrm{R}=\mathrm{CO}_{2}$ Et $81 \%$

4i $\mathrm{R}=\mathrm{CN} 52 \%$

4j $\mathrm{R}=\mathrm{NO}_{2} 40 \%$

$4 \mathbf{k}=\mathrm{CF}_{3} 43 \%$

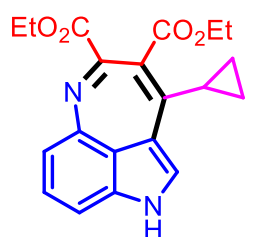

4q $58 \%$

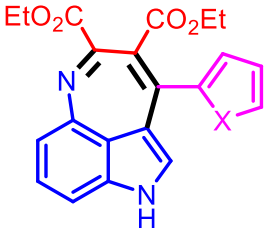

4n $X=052 \%$

$40 X=S 46 \%$

$4 \mathrm{r} R=\mathrm{F} 34 \%$

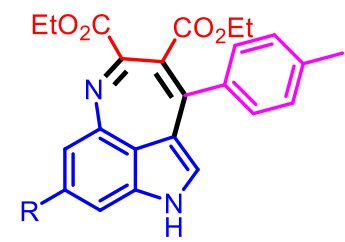

4s $\mathrm{R}=\mathrm{Br} 45 \%$

$4 \mathrm{t} \mathrm{R}=\mathrm{CO}_{2} \mathrm{Me} 52 \%$

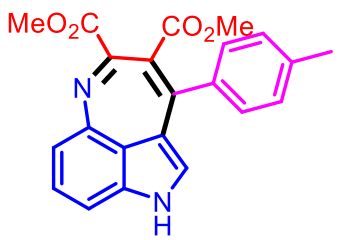

4v $66 \%$

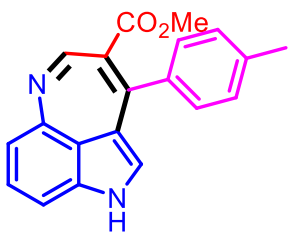

4w $53 \%$

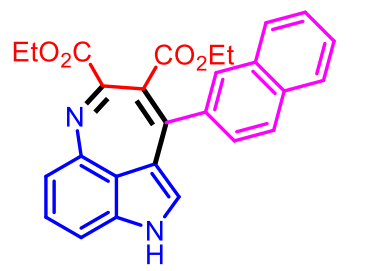

$4 \mathrm{~m} 69 \%$<smiles>CCOC(=O)C1=Nc2cccc3[nH]cc(c23)C(CCc2ccccc2)=C1C(=O)OCC</smiles>

4p $43 \%$

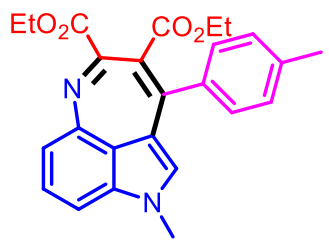

4u $54 \%$

Scheme 2 Substrate scope of the $\mathrm{Cu}(\mathrm{OTf})_{2}$-catalyzed three-component reactions of 4 -aminoindoles, alkynes and aldehydes.
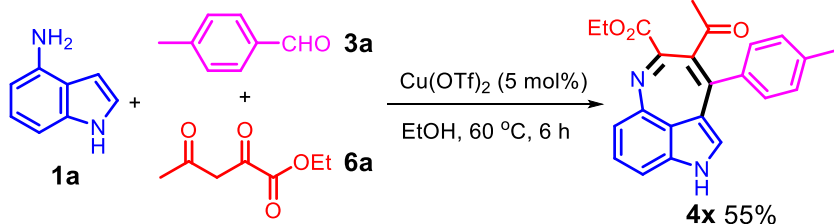

Scheme 3 Three-component reactions of 1a, 3a and $\mathbf{6 a}$. 


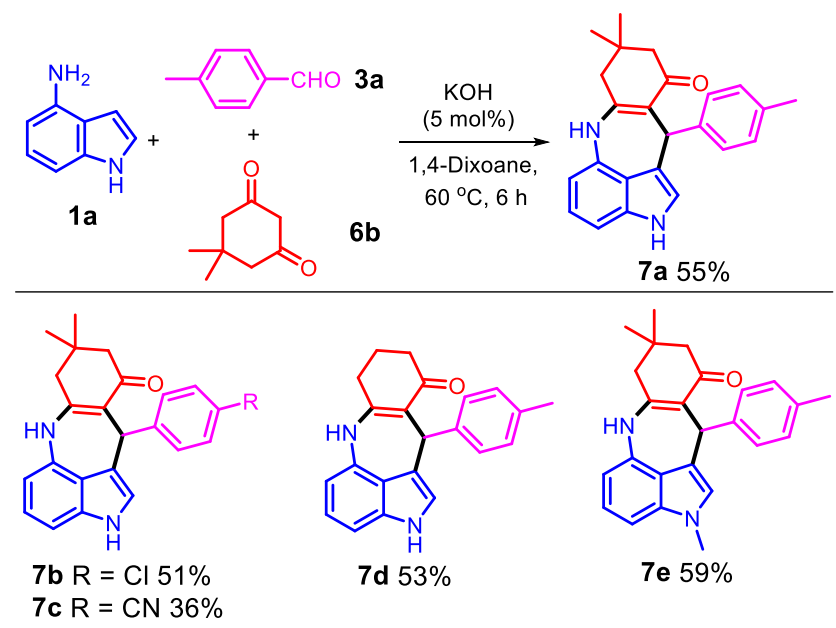

Scheme 4 Three-component reactions of 4-aminoindoles, aromatic aldehydes and 1,3-cyclohexanediones.

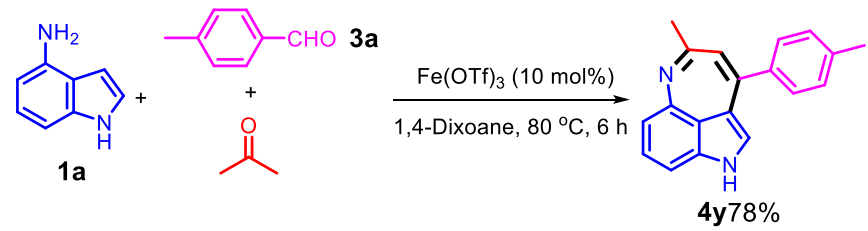

with $\mathrm{Cu}(\mathrm{OTf})_{2}$ catalyst, yield $=19 \%$
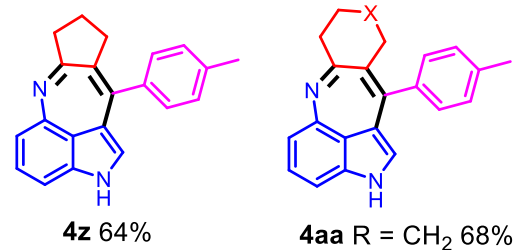

4ab $\mathrm{R}=\mathrm{O} 80 \%$

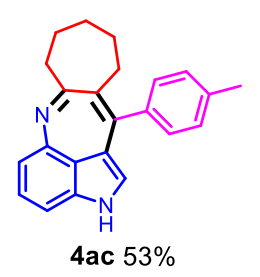

Scheme 5 Three-component reaction of 1a, 3a and a ketone catalyzed by $\mathrm{Fe}(\mathrm{OTf})_{3}$.

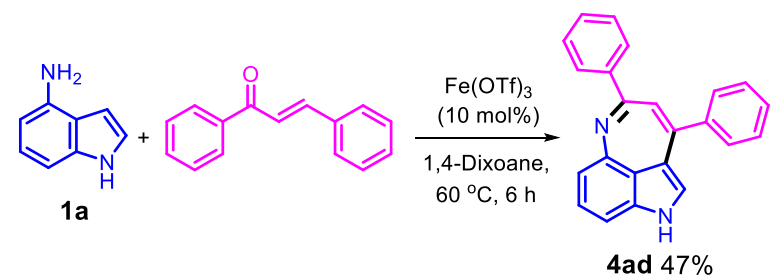

Scheme 6 The reaction of $1 \mathrm{a}$ and chalcone. 


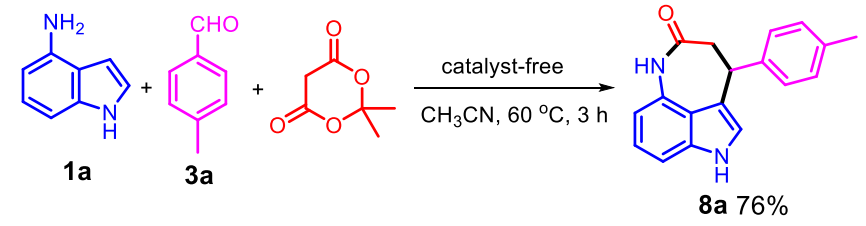

Scheme 7 Three-component reaction of 1a, 3a and Meldrum's acid. 